\title{
LEARNING OF REACTION RATES WITH NESTED CURRICULAR ARRANGEMENT WHICH IS COMBINED WITH CONNECTED CURRICULAR ARRANGEMENT TO IMPROVE CRITICAL THINKING SKILLS OF THE STUDENTS
}

\author{
Khoirotus Sa'adah*', Suyono ${ }^{2}$ \\ ${ }^{1,2}$ Jurusan Kimia FMIPA Universitas Negeri Surabaya \\ *Corresponding author: khoirotussaadah69@gmail.com
}

\begin{abstract}
This study aims to evaluate a learning of reaction rates with nested curricular arrangement which was combined with connected curricular arrangement to improve student's critical thinking skills. The evaluation of this study was based on the result of data collecting toward the implementation of learning, students' activities, learning outcomes, critical thinking skills, and students' responses. This study was conducted using scientific inquiry. The research design used in this study was one group pretest-posttest design including pre-experimental research. The subjects of this study were 36 X graders of MIPA 8 at SMAN 1 Manyar Gresik. The result of this study showed that the implementation of a learning of reaction rates with nested curricular arrangement which was combined with connected curricular arrangement to improve student's critical thinking skills was in very high value category with percentage of agreement around $\geq 75 \%$ and value of the relevant students' activity was greater than the percentage of the irrelevant students' activity so that it has a better category. The students' learning outcomes and critical thinking skills have significantly improved after conducting a learning about reaction rates with nested curricular arrangement which was combined with connected curricular arrangement which was analyzed using t-test. However, there were some students get post-test score under the expected standard value. This learning about reaction rates with nested curricular arrangement which was combined with connected curricular arrangement receives a positive responses from the students of $87.22 \%$ by collecting data using a questionnaire response.
\end{abstract}

Keywords: Critical Thinking Skills, Inquiry, Nested, Connected.

\section{PENDAHULUAN}

Perkembangan ilmu pengetahuan, teknologi dan informasi yang semakin cepat menyebabkan perlunya mempersiapkan generasi yang dapat berpikir secara logis, kritis, kreatif, serta dapat mengatasi masalah-masalah dalam kehidupan sekitarnya dengan baik. Langkah yang harus dilakukan adalah dengan memperbaiki sistem pendidikan di Indonesia.

Pada kurikulum 2013 peserta didik diharapkan menjadi individu yang kritis, kreatif, bertanggung jawab, peduli terhadap diri serta lingkungannya. Salah satu tujuan utama pembelajaran kurikulum 2013 adalah untuk meningkatkan keterampilan berpikir kritis peserta didik [1]. Adapun pembelajaran yang perlu untuk dilatihkan keterampilan berpikir kritis salah satunya adalah mata pelajaran IPA. Mata pelajaran IPA seharusnya diperkaya materi yang dapat melatihkan keterampilan berpikir kritis peserta didik yang sesuai dengan standar internasional [2].

Salah satu mata pelajaran IPA adalah kimia. Pada mata pelajaran kurikulum 2013, kimia termasuk dalam mata pelajaran yang sulit [3]. Hal ini terbukti melalui hasil Ujian Nasional (UNAS) pada jenjang SMA mata pelajaran kimia secara nasional tahun 2016/2017 menunjukkan bahwa soal yang memiliki indikator faktor-faktor laju reaksi yang membutuhkan keterampilan berpikir kritis secara nasional masih sebanyak $52 \%$ peserta didik yang memilih jawaban yang benar. Selain itu konsep yang termuat pada materi laju reaksi mampu memunculkan proses kognitif [4]. Sedangkan pembelajaran materi laju reaksi yang memiliki proses kognitif dapat digunakan untuk melatihkan keterampilan berpikir kritis [5]. 
Model pembelajaran terpadu dapat melatihkan keterampilan berpikir kritis peserta didik dan pembelajaran menjadi lebih bermakna [6]. Nested yang merupakan salah satu model pembelajaran terpadu yang memiliki arti tersarang merupakan pembelajaran dengan mengintegrasikan beberapa keterampilan untuk dilatihkan selama pembelajaran dalam satu disiplin ilmu [7]. Penataan kurikuler nested dapat meningkatkan keterampilan berpikir kritis peserta didik pada materi laju reaksi yang sesuai dengan hasil penelitian yang mengungkapkan bahwa keterampilan berpikir kritis peserta didik pada komponen interpretasi, analisis, eksplanasi, dan inferensi meningkat setelah dilakukan pembelajaran nested [8].

Selain itu, dalam penelitian ini pembelajaran tidak hanya dilakukan penataan kurikuler nested tetapi juga penataan kurikuler connected. Hal ini dikarenakan terdapat hasil penelitian yang mengungkapkan bahwa model connected yang diterapkan pada materi sistem peredaran darah dapat meningkatkan hasil belajar peserta didik [9]. Penataan kurikuler connected merupakan model pembelajaran terpadu dengan menghubungkan materi/konsep yang akan disampaikan dengan materi/konsep lain yang relevan. Penataan kurikuler connected dapat memperkuat materi/konsep (content) yang akan disampaikan, yakni pada pembelajaran ini berupa materi laju reaksi [7].

Pembelajaran dapat dievaluasi dan diketahui keberhasilannya melalui pengamatan terhadap keterlaksanaan guru dalam pembelajaran, aktivitas peserta didik dan respon dari peserta didik pada penelitian ini. Selain itu, untuk mengetahui apakah penataan kurikuler nested dapat berjalan dengan baik adalah dengan mengetahui perubahan keterampilan berpikir kritis peserta didik serta pada penataan kurikuler connected yakni dengan mengetahui perubahan hasil belajar mereka. Guru harus mengikuti prinsip-prinsip tertentu agar pembelajaran dapat berjalan sesuai dengan yang diharapkan [10]. Terdapat tujuh prinsip pembelajaran yang diantaranya berupa keaktifan peserta didik dan balikan (respon) dari peserta didik [11].

Berdasarkan uraian di atas, maka peneliti bermaksud melakukan penelitian berupa pembelajaran laju reaksi dengan penataan kurikuler nested yang dipadukan dengan penataan kurikuler connected untuk meningkatkan keterampilan berpikir kritis peserta didik.

\section{METODE}

Jenis penelitian yang dilakukan adalah pre-experimental dengan "One Group Pre-testPost-test Design". Subjek penelitian yakni 36 peserta didik kelas X SMAN 1 Manyar Gresik pada semester genap 2018/2019. Penelitian ini berlangsung sebanyak 2 kali pertemuan yakni mulai tanggal 15 Januari s/d 1 Februari 2019. Desain penelitian ini digambarkan sebagai berikut:

Keterangan:

$$
\mathrm{O}_{1} \mathrm{X} \mathrm{O}_{2}
$$

$\mathrm{O}_{1}=$ pretest hasil belajar/keterampilan berpikir kritis.

$\mathrm{X}=$ perlakuan, yakni penataan kurikuler nested yang dipadukan dengan penataan kurikuler connected dengan sintaks inquiry ilmiah

$\mathrm{O}_{2}=$ posttest hasil belajar/keterampilan berpikir kritis.

Prosedur penelitian pada tahap pertama yakni persiapan. Pada tahap ini perangkat dan instrumen pembelajaran divalidasi oleh 3 validator yakni 2 dosen kimia Unesa dan 1 guru kimia SMAN 1 Manyar Gresik. Pada tahap kedua yakni tahap pelaksanaan dilakukan pembelajaran dengan penataan kurikuler nested yang dipadukan dengan penataan kurikuler connected dan pengumpulan data penelitian. Teknik pengumpulan data pada penelitian ini melalui metode observasi (meliputi keterlaksanaan penataan kurikuler nested yang dipadukan dengan penataan kurikuler connected serta aktivitas peserta didik), metode tes (meliputi hasil belajar dan keterampilan berikir kritis), serta metode angket berupa respon peserta didik.

Tahap penelitian ketiga yakni tahap analisis. Analisis terhadap data keterlaksanaan penataan kurikuler nested yang dipadukan dengan penataan kurikuler connected menggunakan skala Likert [12]. Keterlaksanaan dikatakan efektif dilakukan apabila Persentase nilai pengamatan keterlaksanaan $\geq 61 \%$ dengan menggunakan rumus:

$\%$ keterlaksanaan $=\frac{\text { skor rata-rata }}{\text { skor } \text { maksimal }} \times 100 \%$

Kesepakatan penilaian oleh pengamat dapat diketahui dengan percentage of agreement dimana ketiga pengamat dikatakan sepakat apabila persentasenya $\geq 75 \%$ [13].

Analisis aktivitas peserta didik dikatakan baik apabila persentase nilai pengamatan 
aktivitas yang relevan lebih besar daripada aktivitas yang tidak relevan dengan rumus sebagai berikut:

$\%$ aktivitas $=\frac{\sum \text { frekuensi yang muncul }}{\sum \text { frekuensi aktivitas keseluruhan }} \times 100 \%$

Analisis data hasil belajar dan keterampilan berpikir kritis peserta didik yang diperoleh dari nilai pretest dan posttest dilakukan menggunakan analisis uji $\mathrm{t}$ untuk mengetahui perbedaan nilai hasil belajar dan keterampilan berpikir kritis peserta didik sebelum dan sesudah pembelajaran dengan hipotesis uji sebagai berikut:

$\mathrm{H}_{0}$ : Tidak terdapat perubahan yang signifikan terhadap hasil belajar/keterampilan berpikir kritis peserta didik sebelum dan sesudah pembelajaran.

$\mathrm{H}_{1}$ : Terdapat perubahan yang signifikan terhadap hasil belajar/keterampilan berpikir kritis pesertadidik sebelum dan sesudah pembelajaran.

Apabila $\mathrm{H}_{0}$ ditolak dan $\mathrm{H}_{1}$ diterima maka penataan kurikuler nested yang dipadukan dengan penataan kurikuler connected berpengaruh terhadap perubahan berupa peningkatan pada hasil belajar/keterampilan berpikir kritis obyek penelitian. Hasil belajar dikatakan baik apabila nilainya lebih dari nilai KKM yakni $\geq 80$. Keterampilan berpikir kritis dikatakan baik apabila mengalami peningkatan signifikan pada setiap komponen keterampilan berpikir kritis dan memperoleh nilai $\geq 80$ setelah dilakukan pembelajaran.

Analisis data respon peserta didik dilakukan menggunakan skala Guttman [12]. Respon peserta didik dikatakan baik apabila respon positif peserta didik $\geq 61 \%$ menggunakan rumus:

$$
\% \text { respon positif }=\frac{\sum \text { respon } \text { positif }}{\sum \text { respon total }} \times 100 \%
$$

\section{HASIL DAN PEMBAHASAN}

\section{Validasi dan Perangkat Pembelajaran}

Sebelum dilaksanakan penelitian, perangkat dan instrumen pembelajaran terlebih dahulu di telaah dan divalidasi. Berdasarkan validasi yang dilakukan pada perangkat dan instrumen pembelajaran diperoleh persentase nilai silabus sebesar 83,33\%; RPP sebesar $81,08 \%$, LKPD sebesar 88,54\%; lembar pengamatan keterlaksanaan pembelajaran sebesar $73,33 \%$, rubrik pengamatan keterlaksanaan sebesar 80,56\%; lembar pengamatan aktivitas peserta didik sebesar $77,78 \%$; pretest $\mathrm{KBK}$ sebesar 78,33\%; soal hasil belajar sebesar 78,33\%; dan lembar angket respon peserta didik sebesar 77,78\%. Dari hasil validasi tersebut dapat dikatakan bahwa perangkat dan instrumen pembelajaran valid untuk digunakan [12].

\section{Keterlaksanaan Pembelajaran}

Pembelajaran laju reaksi dengan penataan kurikuler nested yang dipadukan dengan penataan kurikuler connected pada penerapannya menggunakan sintaks model inquiry ilmiah [14]. Adapun sintaksi model inquiry ilmiah terdiri dari 5 fase. Fase 1 yakni perlibatan (engage), fase 2 yakni penyelidikan (explore), Fase 3 yakni penjelasan (explain), fase 4 yakni penerapan (elaborate), dan fase 5 yakni penilaian (evaluate). Pembelajaran ini dilakukan selama 2 kali pertemuan dengan kegiatan pretest dan posttest dilaksanakan di luar jam pembelajaran. Adapun sebelum dilakukan pembelajaran laju reaksi maka dilakukan pembelajaran prasyarat berupa konsepkonsep yang diperlukan untuk penelitian ini namun belum diajarkan pada obyek penelitian. Pengamatan ini dilakukan oleh 3 pengamat dengan mengetahui kesepakatan atas nilai mereka menggunakan percentage of agreement. Data hasil keterlaksanaan penataan kurikuler nested yang dipadukan dengan penataan kurikuler connected selama dua kali pertemuan disajikan pada Gambar 1.

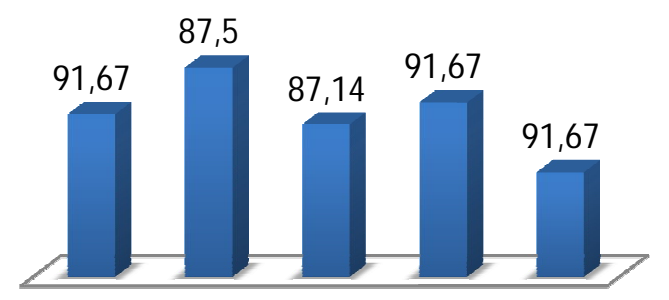

Fase 1 Fase 2 Fase 3 Fase 4 Fase 5

- Persentase (\%)

Gambar 1. Rata-Rata Persentase Keterlaksanaan Pembelajaran pada Setiap Fase Seluruh Pertemuan

Hasil pengamatan keterlaksanaan menunjukkan persentase nilai rata-rata sebesar 90,27\% dengan kategori sangat baik. Adapun ketiga pengamat sepakat atas penilaian mereka dikarenakan percentage of agreement pada setiap fase mencapai nilai $\geq 75 \%$. 


\section{Aktivitas Peserta Didik}

Aktivitas peserta didik berupa perilaku peserta didik selama pembelajaran yang sesuai dengan penataan kurikuler nested, penataan kurikuler connected seterampilan berpikir kritis, dan model inquiry ilmiah. Pengumpulan data aktivitas menggunakan metode obervasi dengan diamati oleh 6 orang pengamat di mana setiap pengamat mengamati satu kelompok menggunakan lembar observasi aktivitas peserta didik yang terdiri dari tabel yang berisi kolom aktivitas peserta didik yang relevan dan tidak relevan. Berikut disajikan data persentase ratarata aktivitas peserta didik pada dua pertemuan dalam Tabel 1.

Tabel 1. Data Persentase Aktivitas Peserta Didik

\begin{tabular}{|c|c|c|c|}
\hline No. & Aktivitas & Pert-1 & Pert-2 \\
\hline 1 & $\begin{array}{l}\text { Meng-Connected- } \\
\text { kan materi laju } \\
\text { reaksi }\end{array}$ & 6,22 & 3,98 \\
\hline 2 & $\begin{array}{l}\text { Duduk dan ber- } \\
\text { disukusi }\end{array}$ & 4,12 & 4,61 \\
\hline 3 & $\begin{array}{l}\text { Mengidentifikasi } \\
\text { masalah }\end{array}$ & 4,72 & 6,61 \\
\hline 4 & $\begin{array}{l}\text { Merumuskan Ma- } \\
\text { salah }\end{array}$ & 6,78 & 5,97 \\
\hline 5 & $\begin{array}{l}\text { Menuliskan hipo- } \\
\text { tesis }\end{array}$ & 5,41 & 7,32 \\
\hline 6 & $\begin{array}{l}\text { Menentukan vari- } \\
\text { abel }\end{array}$ & 6,07 & 6,65 \\
\hline 7 & $\begin{array}{l}\text { Melakukan per- } \\
\text { cobaan }\end{array}$ & 11,12 & 10,68 \\
\hline 8 & $\begin{array}{l}\text { Mengisi/membuat } \\
\text { tabel data }\end{array}$ & 6,70 & 5,97 \\
\hline 9 & Membuat grafik data & 7,38 & 4,67 \\
\hline 10 & Menganalisis data & 8,77 & 8,57 \\
\hline 11 & $\begin{array}{l}\text { Menalar gambar dan } \\
\text { pernyataan }\end{array}$ & 6,07 & 5,28 \\
\hline 12 & $\begin{array}{l}\text { Menghubungkan } \\
\text { data dengan teori } \\
\text { tumbukan }\end{array}$ & 6,07 & 4,61 \\
\hline 13 & $\begin{array}{l}\text { Menuliskan sim- } \\
\text { pulan percobaan }\end{array}$ & 4,12 & 7,32 \\
\hline 14 & $\begin{array}{l}\text { Mengkomunikasikan } \\
\text { hasil percobaan }\end{array}$ & 4,12 & 3,98 \\
\hline 15 & $\begin{array}{l}\text { Menjawab soal } \\
\text { aplikasi }\end{array}$ & 8,14 & 7,95 \\
\hline 16 & $\begin{array}{l}\text { Melakukan aktivitas } \\
\text { tidak relevan. }\end{array}$ & 4,12 & 3,98 \\
\hline
\end{tabular}

Berdasarkan Tabel 1 aktivitas peserta didik yang paling banyak membutuhkan waktu untuk menuntaskannya adalah aktivitas melakukan percobaan. Hal ini dikarenakan aktivitas tersebut dilakukan pada 2 faktor laju reaksi sekaligus dalam satu pertemuan sehingga membutuhkan waktu yang lama bagi peserta didik untuk melakukan aktivitas ini. Diketahui bahwa aktivitas peserta didik yang relevan lebih besar dari aktivitas peserta didik yang tidak relevan sehingga aktivitas peserta didik pada penelitian ini dikatakan baik. Semua aktivitas peserta didik dilakukan sesuai dengan fasenya dan relevan dengan keterlaksanaan guru dalam mengelola pembelajaran sehingga data aktivitas peserta didik ini dapat digunakan sebagai pendukung dari data keterlaksanaan pembelajaran.

\section{Hasil Belajar Peserta Didik}

Pembelajaran akan berjalan dengan maksimal apabila pembelajaran seseorang dapat merubah tingkah lakunya mulai dari afektif, kemampuan kognitif, dan keterampilannya [15]. Data hasil belajar ini merupakan hasil dari penataan kurikuler connected pada pembelajaran laju reaksi dikarenakan tujuan dari penataan kurikuler connected adalah memperkuat konsep/materi dengan cara menghubungkan materi satu dengan materi lain yang relevan. Pengumpulan data hasil belajar menggunakan metode tes sebelum dan sesudah pembelajaran dengan lembar soal yang berisi 10 soal pilihan ganda pada masing-masing pretest dan posttest. Hasil belajar dikatakan tuntas apabila peserta didik memperoleh nilai posttest lebih tinggi dari nilai KKM SMAN 1 Manyar Gresik yakni 80. Analisis hasil belajar peserta didik menggunakan analisis uji-t.

Hasil belajar peserta didik memperoleh Sig. (2-tailed) sebesar 0,000 yakni $\leq 0,05$ yang menunjukkan bahwa terdapat perbedaan yang signifikan pada data pretest dan posttest. Pada analisis tersebut juga diperoleh $t$ hitung sebesar 24, 133. Adapun t tabel dari data penelitian ini adalah 2,042 sehingga t hitung > t tabel. Hal ini menunjukkan bahwa $\mathrm{H}_{0}$ ditolak yang berarti terdapat perubahan (peningkatan) terhadap hasil belajar peserta didik setelah dilakukan pembelajaran laju reaksi dengan penataan kurikuler nested yang dipadukan dengan penataan kurikuler connected. Kenaikan hasil belajar peserta didik dapat dilihat dalam Gambar 2. 


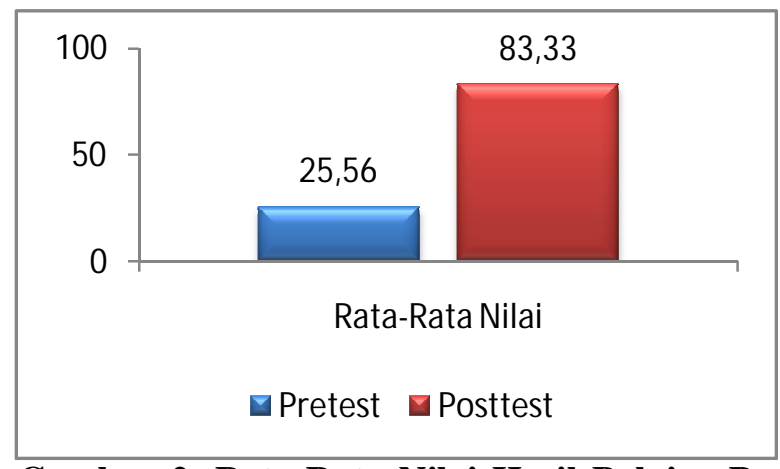

Gambar 2. Rata-Rata Nilai Hasil Belajar Peserta Didik

Berdasarkan Gambar 2 dapat dilihat bahwa hasil belajar peserta didik mengalami kenaikan yang signfikan yakni sebesar $57,77 \%$. Hal ini membuktikan bahwa pembelajaran laju reaksi dengan penataan kurikuler nested yang dipadukan dengan penataan kurikuler connected dapat meningkatkan hasil belajar peserta didik.

\section{Keterampilan Berpikir Kritis Peserta Didik}

Pada pembelajaran laju reaksi dengan penataan kurikuler nested yang dipadukan dengan penataan kurikuler connected, keterampilan berpikir kritis yang dilatihkan mencakup 5 komponen yakni interpretasi, analisis, evaluasi, eksplanasi, dan inferensi. Data keterampilan berpikir kritis peserta didik ini merupakan hasil dari penataan kurikuler nested pada pembelajaran laju reaksi. Hal ini dikarenakan penataan kurikuler nested merupakan penyarangan keterampilan pada pembelajaran sehingga dengan adanya penataan kurikuler nested ini dapat melatihkan keterampilan berpikir kritis. Pengumpulan data keterampilan berpikir kritis menggunakan metode tes dengan lembar soal yang berisi 10 soal uraian yang mencakup 5 komponen keterampilan berpikir kritis pada submateri faktor-faktor yang mempengaruhi laju reaksi pada masing-masing pretest dan posttest. Keterampilan berpikir kritis peserta didik dikatakan baik apabila memperoleh nilai posttest lebih dari 80 . Analisis keterampilan berpikir kritis peserta didik menggunakan analisis uji-t.

Hasil analisis data keterampilan berpikir kritis peserta didik yang menggunakan uji-t memperoleh Sig. (2-tailed) sebesar 0,000 yakni $\leq$ 0,05 yang menunjukkan bahwa terdapat perbedaan yang signifikan pada data pretest dan posttest keterampilan berpikir kritis peserta didik. Pada analisis tersebut juga diperoleh $t$ hitung sebesar 33,033. Adapun $\mathrm{t}$ tabel dari data penelitian ini sebesar 2,042 sehingga $t$ hitung $>\mathrm{t}$ tabel. Hal ini menunjukkan bahwa $\mathrm{H}_{0}$ ditolak yang berarti terdapat perubahan (peningkatan) terhadap keterampilan berpikir kritis peserta didik setelah dilakukan pembelajaran laju reaksi dengan penataan kurikuler nested yang dipadukan dengan penataan kurikuler connected. Kenaikan hasil tes keterampilan berpikir kritis pada masing-masing komponen peserta didik

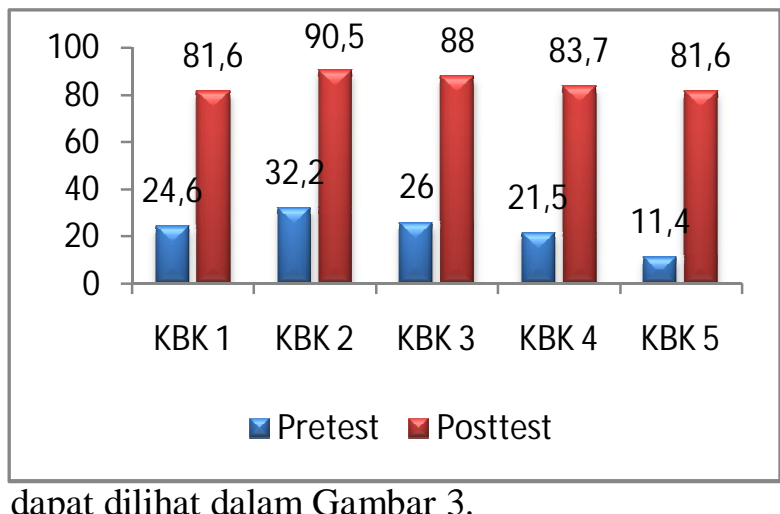

\section{Gambar 3. Rata-Rata Nilai Keterampilan Berpikir Kritis pada Setiap Kom- ponen}

Pada Gambar 3 menunjukkan hasil tes keterampilan berpikir kritis yang terdiri dari 5 komponen yakni komponen interpretasi (KBK 1), komponen analisis (KBK 2), komponen evaluasi (KBK 3), komponen eksplanasi (KBK 4), dan komponen inferensi (KBK 5). Pengukuran hasil keterampilan berpikir kritis menggunakan tes berupa soal-soal dalam lembar kerja peserta didik (LKPD) yang memuat komponen-komponen keterampilan berpikir kritis. Kemampuan berpikir kritis komponen interpretasi pada penelitian ini diterapkan dalam soal berupa menentukan rumusan masalah dan variabel percobaan pada fenomena yang diberikan. Adapun kemampuan berpikir kritis komponen analisis pada penelitian ini diterapkan dalam soal menganalisis hasil percobaan. Kemampuan berpikir kritis komponen evaluasi diterapkan pada soal berupa menghubungkan data hasil percobaan dengan teori yang sudah diketahui peserta didik sebelumnya, dalam hal ini teori tumbukan. Penerapan soal pada kemampuan keterampilan berpikir kritis komponen eksplanasi berupa pemberian fenomena baru dan peserta didik diminta untuk menjelaskan fenomena tersebut berdasarkan konsep yang telah mereka terima dari mengerjakan soal-soal sebelumnya. Kemampuan berpikir kritis komponen inferensi diterapkan dalam soal berupa membuat hipotesis 
dari fenomena yang diberikan serta membuat simpulan berdasarkan analisis percobaan yang telah dibuat di soal sebelumnya.

Dilihat dari gambar tersebut, pretest peserta didik pada semua komponen keterampilan berpikir kritis memperoleh presentasi nilai rendah yang menandakan bahwa keterampilan berpikir kritis peserta didik pada materi laju reaksi masih tergolong rendah. Sedangkan nilai posttest peserta didik pada semua komponen keterampilan berpikir kritis memperoleh presentase nilai yang tinggi yang menandakan bahwa keterampilan berpikir kritis peserta didik sudah terlatih setelah dilakukan pembelajaran. Semua komponen keterampilan berpikir kritis peserta didik mengalami kenaikan setelah dilakukan pembelajaran. Hal ini membuktikan bahwa pembelajaran laju reaksi dengan penataan kurikuler nested yang dipadukan dengan penataan kurikuler connected dapat meningkatkan keterampilan berpikir peserta didik.

\section{Respon Peserta Didik}

Respon peserta didik adalah tanggapan peserta didik setelah melakukan pembelajaran laju reaksi dengan penataan kurikuler nested yang dipadukan dengan penataan kurikuler connected. Pengumpulan data respon peserta didik menggunakan angket respon peserta didik. Lembar angket respon diberikan kepada peserta didik setelah dilakukan pembelajaran yakni pada saat kegiatan posttest. Angket respon pada penelitian ini terdiri dari respon positif dan respon negatif terkait pembelajaran yang dilakukan. Data rata-rata persentase respon peserta didik disajikan dalam Gambar 4.

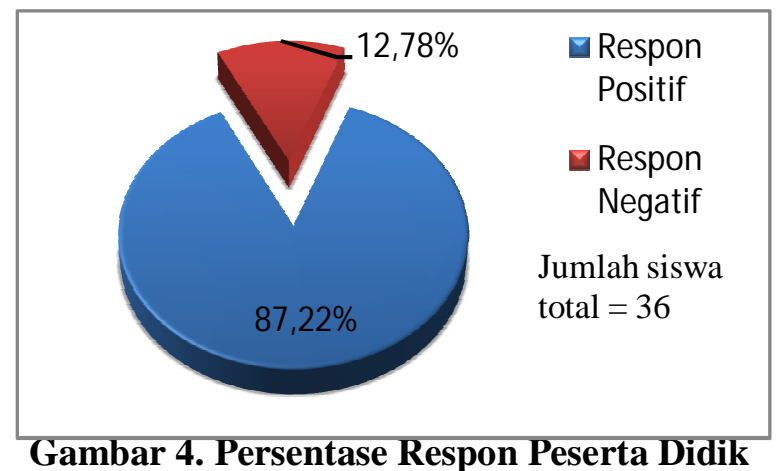

Hasil analisis respon peserta didik menunjukkan rata-rata persentase respon positif sebesar $87,22 \%$. Hal ini menunjukkan bahwa respon positif memiliki persentase nilai $\geq 61 \%$ sehingga dapat dikatakan bahwa respon peserta didik terhadap pembelajaran laju reaksi dengan penataan kurikuler nested yang dipadukan dengan penataan kurikuler connected adalah baik.

\section{SIMPULAN DAN SARAN}

Simpulan dari penelitian ini berdasarkan hasil penelitian dan pembahasan yang telah dibuat adalah sebagai berikut:

1. Keterlaksanaan pembelajaran laju reaksi dengan penataan kurikuler nested yang dipadukan dengan penataan kurikuler connected memiliki kriteria penilaian sangat baik dengan percentage of agreement $\geq 75 \%$ yang menandakan bahwa ketiga pengamat sepakat terhadap nilai tersebut.

2. Aktivitas peserta didik yang relevan lebih besar dari aktivitas peserta didik yang tidak relevan selama pembelajaran laju reaksi dengan penataan kurikuler nested yang dipadukan dengan penataan kurikuler connected sehingga dapat dikatakan bahwa aktivitas peserta didik baik dan mendukung kegiatan pembelajaran.

3. Hasil belajar peserta didik meningkat secara signifikan dengan taraf kepercayaan sebesar 95\% yang menunjukkan bahwa pembelajaran laju reaksi dengan penataan kurikuler nested yang dipadukan dengan penataan kurikuler connected terbukti berpengaruh terhadap perubahan (kenaikan) hasil belajar peserta peserta didik.

4. Keterampilan berpikir kritis peserta didik meningkat secara signifikan pada semua komponen dengan taraf kepercayaan sebesar 95\% yang menunjukkan bahwa pembelajaran laju reaksi dengan penataan kurikuler nested yang dipadukan dengan penataan kurikuler connected terbukti berpengaruh terhadap perubahan (kenaikan) keterampilan berpikir kritis peserta peserta didik.

5. Mayoritas peserta didik yakni sebesar $87,22 \%$ memberikan respon positif terhadap pembelajaran laju reaksi dengan penataan kurikuler nested yang dipadukan dengan penataan kurikuler connected yang menunjukkan bahwa respon peserta didik baik terhadap pembelajaran yang dilakukan.

Saran untuk penelitiaan selanjutnya adalah pembelajaran laju reaksi dengan penataan kurikuler nested yang dipadukan dengan penataan kurikuler connected terbukti dapat meningkatkan hasil belajar serta memperkuat materi melalui penataan kurikuler connected dan

Vol. 4, No. 1, June 2020 (1-7) 
keterampilan berpikir kritis peserta didik melalui penataan kurikuler nested secara signifikan sehingga penataan kurikuler nested dan connected direkomendasikan untuk digunakan pada materi kimia atau materi lain yang memiliki karakteristik sama dengan materi laju reaksi.

\section{DAFTAR PUSTAKA}

[1]. Depdikbud. 2016. PMP Kimia Minat SMA. Direktorat Jenderal Manajemen Pendidikan Dasar dan Menengah Direktorat Pembinaan Sekolah Menengah Atas. Jakarta: Depdikbud

[2]. Paul, Richard and Linda Elder. 2005. The Miniature Guide to Critical Thinking "CONCEPTS \& TOOLS". The Foundation of Critical Thinking: California.

[3]. Chostantika, A. L., Haryono \& Yamtinah, S. 2013. Penerapan Pembelajaran Model Make a Match dan Diskusi Kelompok untuk Meningkatkan Motivasi Berprestasi, Rasa Ingin Tahu, dan Prestasi Belajar pada Materi Hidrokarbon Siswa kelas X-6 di SMA Negeri 2 Boyolali Tahun Ajaran 2011/2012. Jurnal Pendidikan Kimia, II(3): p. 25.

[4]. Musya'idah, Efendy, dan Aman Santoso. 2016. POGIL, Analogi Model FAR, KBI, dan Laju Reaksi. Malang: Universitas Negeri Malang.

[5]. Cowden, D. C., dan Santiago M. F. 2015. Interdisciplinary Explorations: Promoting Critical Thinking via Problem-Based Learning in an Advanced Biochemistry Class. Journal of Chemical Education. 3(93): 464-469.

[6]. Julianti, H. D. R., Atmojo, T. \& Usodo, B. 2014. Eksperimentasi Model Pembelajaran Nested dan Think Pair Share (TPS) dengan Pendekatan Kontekstual pada Materi Pokok Bangun Ruang Sisi Datar Ditinjau dari Kecemasan Belajar Matematika Siswa Kelas
VIII MTs Ponorogo Tahun Pelajaran 2013/2014. Jurnal Elektronik Pembelajaran Matematika, II(8):p.867

[7]. Fogarty, Robin. 2009. How to Integrate the Curricula Third Edition. California: Corwin Herron.

[8]. Rahmadhani, Pradita dan Dian Novita. 2018. Penerapan Model Pembelajaran Guided Inqury dengan Pendekatan Nested untuk Meningkatkan Keterampilan Berpikir Kritis Peserta Didik Kelas XI MIA SMA Negeri 1 Manyar pada Materi Laju Reaksi. Skripsi. Surabaya: FMIPA UNESA.

[9]. Muchsen, Hadijah, Andi Tanra T., Lilies N. T. 2016. Penerapan Pembelajaran IPA Terpadu Tipe Connected dalam Meningkatkan Motivasi dan Hasil Belajar Peserta Didik tentang Materi Sistem Peredaran Darah Manusia di Kelas VIII A SMP Negeri 17 Palu. Jurnal Pendidikan. Palu: Universitas Tadulako.

[10].Arifin, Zainal. 2014. Konsep dan Model Pengembangan Kurikulum. Bandung: PT Rosdakarya Offset.

[11].Dimyati dan Mudjiono. 1999. Belajar dan Pembelajaran. Jakarta: Rineka Cipta.

[12].Riduwan. 2015. Skala Pengukuran Variabelvariabel Penelitian. Bandung: Alfabeta.

[13].Borich, Gary D. 1994. Observation Skill for Effective Teaching. Texas: Macmillan Publishing Company

[14].Bass, Joel L dan T.L.C. Arthur A. Carin. 2009. Methods for Teaching Science as Inquiry. Boston: Pearson \& Allyn and Bacon.

[15].Djamarah, Syaiful Bahri. 2000. Guru dan Anak Didik dalam Interaksi Edukatif. Jakarta: Rineka Cipta. 